\title{
Mirror image hydrocarbons from Tropical and Boreal forests
}

\author{
J. Williams, N. Yassaa, S. Bartenbach, and J. Lelieveld \\ Air Chemistry Department, Max-Planck Institute for Chemistry, J.J. Becher Weg 27, 55020 Mainz, Germany \\ Received: 22 August 2006 - Published in Atmos. Chem. Phys. Discuss.: 29 September 2006 \\ Revised: 8 January 2007 - Accepted: 26 January 2007 - Published: 22 February 2007
}

\begin{abstract}
Monoterpenes, emitted in large quantities by trees to attract pollinators and repel herbivores, can exist in mirror image forms called enantiomers. In this study such enantiomeric pairs have been measured in ambient air over extensive forest ecosystems in South America and northern Europe. For the dominant monoterpene, $\alpha$-pinene, the (-)form was measured in large excess over the (+)-form over the Tropical rainforest, whereas the reverse was observed over the Boreal forest. Interestingly, over the Tropical forest (-)- $\alpha$-pinene did not correlate with its own enantiomer, but correlated well with isoprene. The results indicate a remarkable ecosystem scale enantiomeric fingerprint and a nexus between the biosphere and atmosphere.
\end{abstract}

\section{Introduction}

Monoterpenes and isoprene together make up 55\% of the estimated $1150 \mathrm{TgC}\left(\mathrm{Tg}=10^{12} \mathrm{~g}\right)$ of biogenic volatile organic compounds emitted each year into our atmosphere (Guenther et al., 1995). Monoterpenes alone are comparable to the $150 \mathrm{TgC}_{\mathrm{gr}}{ }^{-1}$ total emissions estimated from all anthropogenic sources including fossil fuel usage and biomass burning (Müller, 1992). Both isoprene and the monoterpenes react rapidly with the atmosphere's primary oxidant OH (Atkinson and Arey, 2003; Fuentes et al., 2000), and are known to impact ozone and produce secondary organic aerosol, thereby affecting the Earth's radiation energy budget (Seinfeld, 2003; Claeys et al., 2004; Williams, 2004). The global effect of these gases on atmospheric chemistry has been assessed by models (Wang et al., 1998; Houweling et al., 1998), however, such work is crucially dependent on emission algorithms which are uncertain, particularly in the case of monoterpenes (Guenther et al., 1995; Shao

Correspondence to: J. Williams

(williams@mpch-mainz.mpg.de) et al., 2001). Leaf scale studies have established that isoprene emissions can be parameterized as a function of light and temperature (Guenther et al., 1995). Unlike isoprene, monoterpenes may be stored in the leaf rather than emitted directly and recently it has been a moot point whether the monoterpene emissions are light dependent or not (Lerdau and Gray, 2003; Tarvainen et al., 2005). Many of the monoterpenes considered in present day models are chiral compounds, which means they exist in two distinct forms that are mirror images called enantiomers. For example $\alpha$ pinene occurs as both (+)- $\alpha$-pinene and ( $(-)-\alpha$-pinene, see Fig. 1, although they are typically measured and modeled together as one substance in ambient air studies. Therefore emission algorithms deduced from studies of $\alpha$-pinene assume both enantiomeric constituents behave similarly (Shao et al., 2001; Tarvainen et al., 2005), although from a biosynthetic point of view, the two enantiomers of a chiral monoterpene often exhibit differences in biological activity (Croteau, 1987). Here we present the first set of monoterpene measurements to resolve these enantiomers in air over large Tropical and Boreal forest ecosystems.

\section{Experimental}

\subsection{Analytical}

For a given pair of monoterpene enantiomers (e.g. (+)and $(-)-\alpha$-pinene, having absolute configurations $(1 \mathrm{R}, 5 \mathrm{R})$ and (1S,5S) $\alpha$-pinene respectively), both compounds have exactly the same molecular formula, mass, and physical properties such as boiling point, freezing point, and density. Nonetheless, such compounds cannot be structurally superimposed, and are distinguishable by their interaction with plane polarized light. Unsurprisingly these compounds are difficult to physically separate from a mixture and no leaf scale emission rate studies to date have resolved these

Published by Copernicus GmbH on behalf of the European Geosciences Union. 


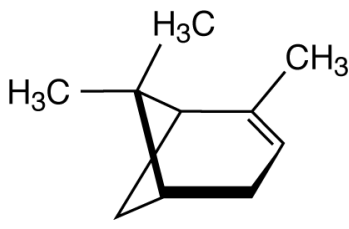

$(+)-\alpha$ - pinene

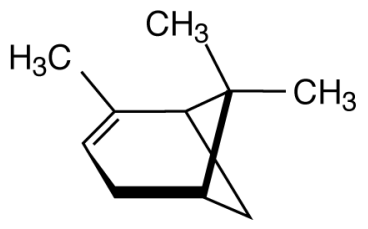

$(-)-\alpha-$ pinene

Fig. 1. Mirror image enantiomers of alpha-pinene. (-)- $\alpha$-pinene $S$ $(1 \mathrm{~S}, 5 \mathrm{~S})$ is labeled (a), and (+)- $\alpha$-pinene R (1R,5R) labeled (b).

enantiomers. For ambient air analysis on an ecosystem scale we exploit the recent development of modified cyclodextrin chromatography columns, which have allowed enantiomers to be resolved from single plant emissions and from essential oils (Yassaa et al., 2001; Yassaa and Williams, 2005). The enantiomers are chromatographically resolved by selective inclusion into the cavity of a chiral macromolecule constructed from glycosidically connected glucose molecules and detected by mass spectrometry.

The GC-MS analysis system used to analyse the cartridges consists of an air concentrating autosampler and a thermal desorber (Markes Int., Pontyclun, UK), coupled to a gas chromatograph (GC6890A, Agilent Technologies, CA, USA) linked to a Mass Selective Detector (MSD 5973 inert) from the same company. All pertinent analysis parameters are summarised in Table 1. Laboratory multipoint calibrations showed good linearity within the concentration ranges measured. One-point calibrations of $250 \mathrm{ml} \mathrm{VOC} \mathrm{standard}$ (Apel-Riemer, CT, USA) and $100 \mathrm{ml}$ of an enantiomeric terpene (Apel-Riemer, CT, USA, stated accuracy 5\%) standard were carried out at the beginning and the middle of each flight analysis for the Tropical data and at 3 hourly intervals for the Boreal forest data. Blanks were taken regularly and showed no high levels for the compounds discussed. The total measurement uncertainties were between 10 and $15 \%$, the detection limit ranged from $0.5 \mathrm{pptv}$ to $5 \mathrm{pptv}$. An example sample from the Tropical rainforest, the boreal forest and a calibration chromatogram are shown in Fig. 2.

Airborne sampling for monoterpenes over the Tropical rainforest was performed using a custom built cartridge sampling device installed within a standard aircraft wingpod, see Fig. 3. The device was mounted underneath the port wing of a Learjet aircraft and operated from within the cabin via a communication cable. The system was designed to collect ambient air samples in flight within 18 cartridges and 18 stainless steel canisters. A flight was typically $3 \mathrm{~h}$ in duration, range ca. $1800 \mathrm{~km}$ so that a cartridge was filled every $10 \mathrm{~min}$. Flights were performed in the daylight from 07:30 17:30 local time. Three identical systems were built to allow rapid changeovers between flights.

For the airborne samples, outside air was drawn by a metal bellows pump (Senior Aerospace, Lambsheim, Germany)

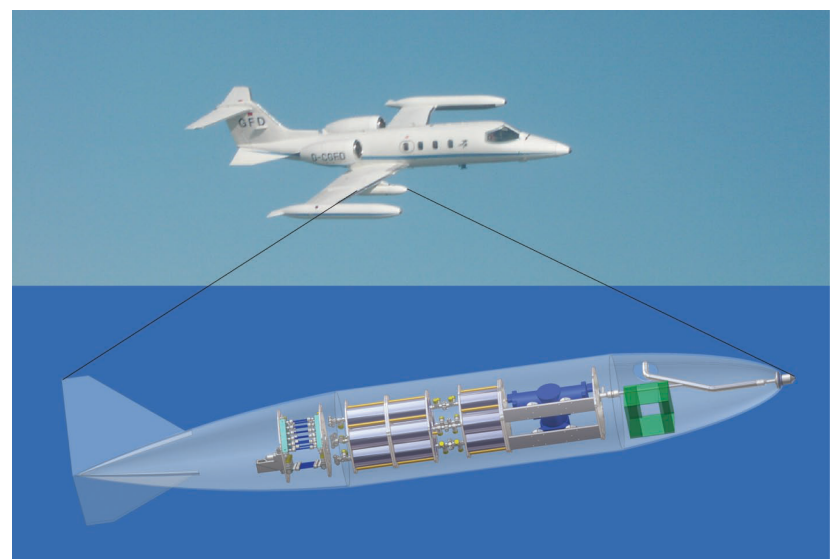

Fig. 2. The wingpod and jet aircraft used for the Tropical rainforest measurements.
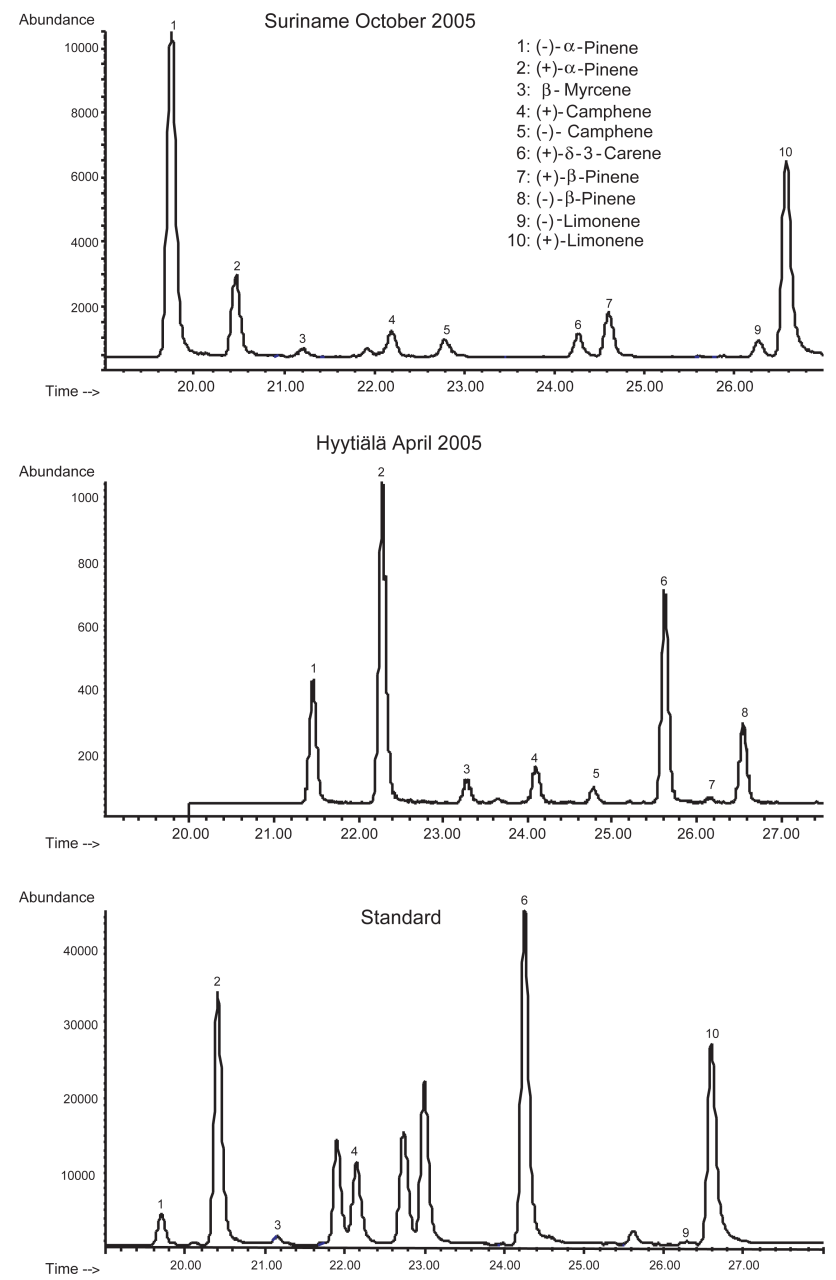

Fig. 3. Example separations using the beta-cyclodextrin column.

into the system through an $8.5 \mathrm{~mm}$ diameter stainless steel inlet located at the front of the wing-pod. The pump was 
Table 1. Sampling, desorption and analysis data for the Tropical rainforest measurement.

\begin{tabular}{|c|c|c|}
\hline Sampling & $\begin{array}{l}\text { Cartridges: } \\
\text { Flow: } \\
\text { Duration: } \\
\text { Volume: }\end{array}$ & $\begin{array}{l}\text { Carbograph I/Carbograph II } \\
200 \mathrm{ml} \mathrm{min}^{-1} \\
5 \mathrm{~min} \\
1 \mathrm{~L}\end{array}$ \\
\hline \multicolumn{3}{|l|}{ Thermal desorption } \\
\hline $\begin{array}{l}\text { Primary desorption } \\
\text { (cartridges) }\end{array}$ & $\begin{array}{l}\text { Prepurge: } \\
\text { Desorption: } \\
\text { Cold trap: }\end{array}$ & $\begin{array}{l}15 \mathrm{~min} \\
10 \mathrm{~min}, 200^{\circ} \mathrm{C} \\
10^{\circ} \mathrm{C}\end{array}$ \\
\hline $\begin{array}{l}\text { Secondary desorption } \\
\text { (cold trap) }\end{array}$ & $\begin{array}{l}\text { Desorption: } \\
\text { Flow Path: }\end{array}$ & $\begin{array}{l}5 \mathrm{~min}, 200^{\circ} \mathrm{C} \\
140^{\circ} \mathrm{C}\end{array}$ \\
\hline \multicolumn{3}{|l|}{ Analysis } \\
\hline Column & \multicolumn{2}{|c|}{$\begin{array}{l}\beta \text {-cyclodextrin chiral capillary column: Cyclodex-B, } \\
30 \mathrm{~m}, 0.256 \mathrm{~mm} \text { I.D., } 0.25 \mu \mathrm{m} \text { film (J\&W Scientific, } \\
\mathrm{CA} \text {, USA) } \\
40^{\circ} \mathrm{C}, 5 \mathrm{~min} \text { hold }, 1.5^{\circ} \mathrm{C} / \mathrm{min} \text { to } 200^{\circ} \mathrm{C}, 5 \text { min hold }\end{array}$} \\
\hline Mass Spectrometer & \multicolumn{2}{|c|}{ EI in Single Ion Mode (SIM) } \\
\hline & $\begin{array}{l}\text { Potential ionization: } \\
\text { Source temperature: }\end{array}$ & $\begin{array}{l}70 \mathrm{eV} \\
230^{\circ} \mathrm{C}\end{array}$ \\
\hline
\end{tabular}

connected to the canisters and the cartridge sampling sections by heated $0.64 \mathrm{~mm}$ stainless steel tubing. Calibrated mass flow-controllers (MKS) regulated the air flow through the system and a custom made processor was used to set the parameters and record the sampling processes. The sample tubes were fitted into the flow path approximately $80 \mathrm{~cm}$ after the pump with Swagelok Ultra-Torr stainless steel fittings (B.E.S.T. GmbH, Maintal, Germany) and sealed with 2-way electromagnetic valves (Fluitronics $\mathrm{GmbH}$, Düsseldorf, Germany) at the entrance and the exit. The valves could be opened and closed simultaneously via the software. During the sampling, the inlet and outlet valves of the selected cartridge are opened and the sample flow $(200 \mathrm{ml} / \mathrm{min})$ passed over the sorbent for $5 \mathrm{~min}$. Cartridges were filled every $10 \mathrm{~min}$ and, up to 17 of the 18 available cartridges (at least one blank was flown i.e. cartridge that was not opened in flight) were filled per measurement flight. To minimise the sample contamination from airport air, the pump was started 5 min after take-off.

Prior to flight, the stainless steel, two-bed sampling cartridges (Carbograph I/ Carbograph II; Markes International, Pontyclun, UK) were cleaned with the Thermoconditioner TC-020 (Markes International, Pontyclun, UK). Cleaning was achieved by purging with helium $6.0(99.9999 \%$, Messer-Griesheim, Germany) for $120 \mathrm{~min}$ at $350^{\circ} \mathrm{C}$ and $30 \mathrm{~min}$ at $380^{\circ} \mathrm{C}$. For storage the cartridges were sealed with brass caps with PTFE ferrules and put into an airtight metal container (Rotilabo, Carl Roth GmbH \& Co, Karlsruhe, Germany). After sampling, the cartridges were stored in a sepa- rate airtight metal container a maximum of $12 \mathrm{~h}$. Shortly before the analysis, the brass caps were exchanged for DiffLokcaps (Markes International, Pontyclun, UK). In total, 152 cartridges were sampled from $0-10 \mathrm{~km}$ altitude and between $6-3.5^{\circ} \mathrm{N}$ and $129-123^{\circ} \mathrm{W}$.

\subsection{Tropical forest location}

The northeast coast of South America in October is an excellent location to study the effects of the unperturbed Tropical rainforest on atmospheric trace gas composition. In October 2005 the ITCZ was located to the north of Suriname at approximately $10-15^{\circ} \mathrm{N}$. Thus at this time of year, although geographically in the Northern Hemisphere, Suriname was atmospherically in the Southern Hemisphere and under the influence of the steady south easterly trade winds. As clean marine boundary layer air advected westwards over the pristine tropical rainforests of French Guyana and Suriname, trace gas exchange occurred over long fetches of pristine rainforest. Trace gases emitted by the forest (e.g. isoprene, monoterpenes) are released into the well-mixed boundary layer $(\sim 1.5 \mathrm{~km})$ and oxidized as the air masses travel westwards. The ground based samples presented here were taken at the Suriname meteorological station of Brownsberg $\left(4^{\circ} 53^{\prime} \mathrm{N}, 55^{\circ} 13^{\prime} \mathrm{W}, 500 \mathrm{~m}\right)$. Ambient air was drawn rapidly (ca. $301 / \mathrm{min}$ ) from the canopy top $(50 \mathrm{~m})$ through a $1.95 \mathrm{~cm}$ diameter shrouded Teflon inlet mounted on a $50 \mathrm{~m}$ telecommunications tower. The tower was sited on a hill $(500 \mathrm{~m})$ adjacent to the Brokopondo Lake. Upwind from the site is 


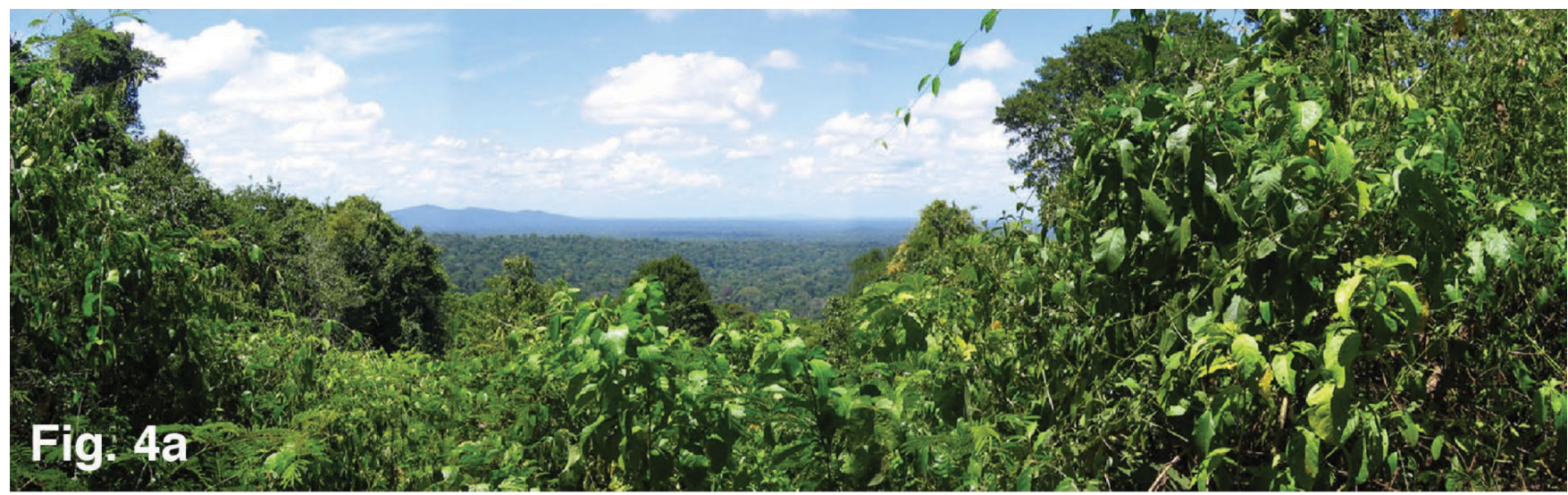

Fig. 4a. A view over the region probed by the aircraft from the ground based site Brownsberg.

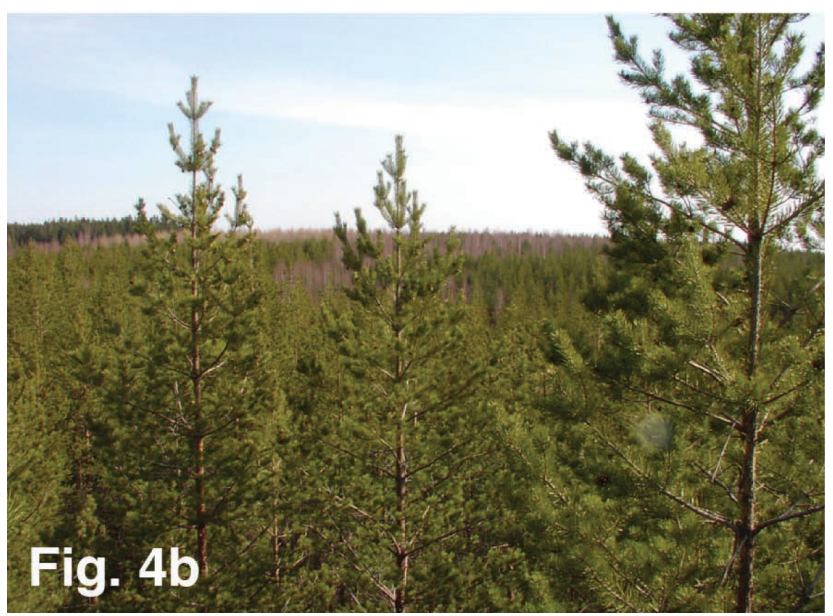

Fig. 4b. The Boreal forest at the Hyytiälä meteorological station, Finland.

$300-400 \mathrm{~km}$ of pristine rainforest before the coast of French Guyana. The ground based site, Brownsberg, was approximately central to the operational area of the aircraft which ranged from $6-3.5^{\circ} \mathrm{N}$ and $129-123^{\circ} \mathrm{W}$. A view from the ground based site is given in Fig. 4a.

\subsection{Boreal forest location}

Chiral and achiral monoterpenes were measured in Scots pine forest in the Hyytiälä $\left(61^{\circ} 51^{\prime} \mathrm{N} 24^{\circ} 17^{\prime} \mathrm{E}\right)$ meteorological station located in the south of Finland. Monoterpenes were sampled at $8 \mathrm{~m}$ height using a thermal desorber (Markes Int., Pontyclun, UK) operated in on-line mode. Volatile Organic Compounds (VOCs) collected in an adsorbent tube by drawing air at $50 \mathrm{ml} / \mathrm{min}$ for $1 \mathrm{~h}$ sampling duration, were thermally desorbed into GC/MS equipped with a $\beta$-cyclcodextrin capillary column and operated with the same conditions as described above. The same calibration procedure was also adopted in boreal forest, in total 150 on-line

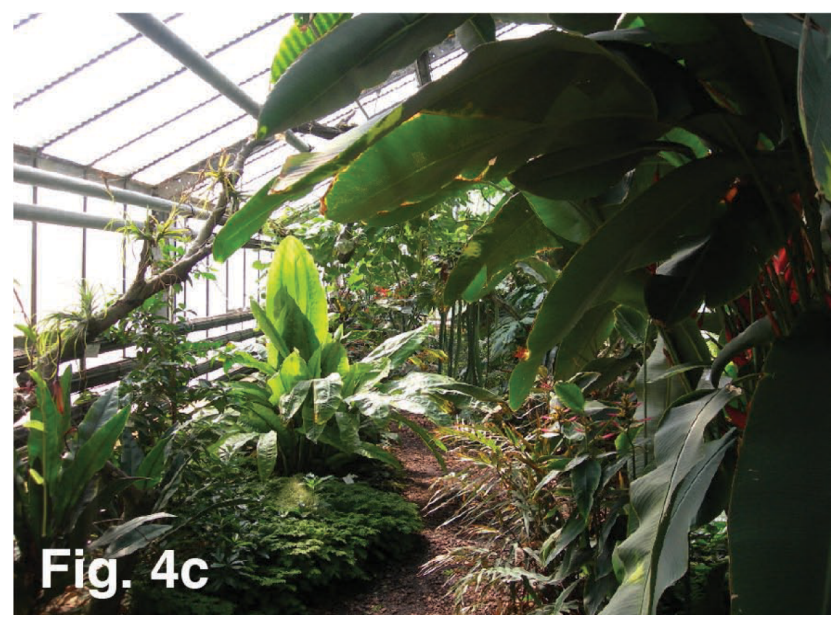

Fig. 4c. Greenhouse in the Mainz Botanical Garden.

samples were taken. Diel profiles of monoterpenes were obtained for one month throughout April 2005. It should be noted that the Scots Pine is weak or not an isoprene emitter and hence isoprene/monoterpene correlations were not compared for the Boreal forest in this work. A picture of the Boreal forest is given in Fig. 4b.

\subsection{Botanical garden location}

For comparison with the Tropical data a further 30 cartridge samples were taken from the Botanical Garden of the Johannes Gutenberg-University which is part of the Institut für Spezielle Botanik in the Department of Biology. The Garden covers an area of nearly 10 ha (3000 sqm under glass) and cultivates some 8500 plant species, varieties and cultivars from all over the world. Cartridges were taken within three large (ca. $300 \mathrm{~m}^{3}$ ) greenhouses (Fig. $4 \mathrm{c}$ ). The sampling procedure was exactly as used in the aircraft samples. The plants within are from various continents. They are kept at 
$30^{\circ} \mathrm{C}$ and high humidity. The distance to the institute where the samples were analyzed is approximately $500 \mathrm{~m}$. All samples were analyzed on the same day as their collection.

\section{Results}

In October 2005, measurements of isoprene as well as chiral and achiral monoterpenes were made from a jet aircraft over a pristine rainforest $\left(5-2^{\circ} \mathrm{N}, 51-58^{\circ} \mathrm{W}\right)$. The distribution of enantiomeric monoterpenes is shown in Fig. 5 for both the Tropical forest in South America (French Guyana, Suriname and Guyana) and a ground based campaign in a Boreal forest (Hyytiälä, Finland) performed in the same year. For the Tropical dataset, the monoterpene species detected in order of decreasing average mixing ratio were: $(-)$ - $\alpha$-pinene $74 \mathrm{pptv},(+)-\beta$-pinene $45 \mathrm{pptv},(-)$-limonene 40 pptv, (+)- $\alpha$-pinene 34 pptv, (+)-camphene 9 pptv, (+)- $\delta$ 3 -carene 9 pptv, (-)-camphene 6 pptv, (+)-limonene 4 pptv. When both enantiomers are summed then the most abundant monoterpene was $\alpha$-pinene accounting about $51 \%$ of the total of measured monoterpenes, consistent with previous rainforest studies (Kesselmeier et al., 2000; Rinne et al., 2002). In the case of $\alpha$-pinene, highlighted green in Fig. 5, the (-)-enantiomer was discovered to be clearly enriched relative to the (+)-enantiomer in $80 \%$ of measurements over the Tropical forest (10 flights), in most cases between 28 times. Additional ground based measurements from the top of the Tropical forest canopy in the same region also showed an enantiomeric excess of ( -$)$ - $\alpha$-pinene throughout the diel cycle. Since both enantiomers react with $\mathrm{OH}$ and $\mathrm{O}_{3}$ at exactly the same rate (Nunes et al., 2005), the dominance of the (-)- $\alpha$-pinene enantiomer over the Tropical forest must be a function of selective emission or uptake rather than chemical removal. Sharply contrasting results were discovered in the Boreal forest of Finland in April 2005 using the same instrumentation. The air over the Boreal forest in spring showed a clear predominance of $(+)-\alpha$-pinene for all samples, see Fig. 5. Interestingly, although at much lower mixing ratios beta-pinene exhibited the reverse enantiomeric discrimination, namely that $(+)-\beta$-pinene predominated over the rainforest. The relative abundance of the monoterpenes over the Boreal forest is comparable to previous measurements (Komenda et al., 2003; Komenda and Koppmann, 2000; Spirig et al., 2004) and the enantiomeric distribution similar to Scots Pine leaf tissue (Persson et al., 1993; Sjödin et al., 1996, 2000; Yassaa and Williams, 2007). As far as we are aware, the only other enantiomeric selective study of emissions in ambient air available in literature examined individual Mediterranean tree species and showed that for some species (-)- $\alpha$-pinene dominated (e.g. Quercus ilex L.) while for others it was (+)- $\alpha$-pinene (e.g. Cypresses and Eucalyptus) (Yassaa et al., 2001). In order to confirm the apparent dominance of $(-)-\alpha$-pinene over the rainforest ecosystem we also tested three mixed-species Tropical
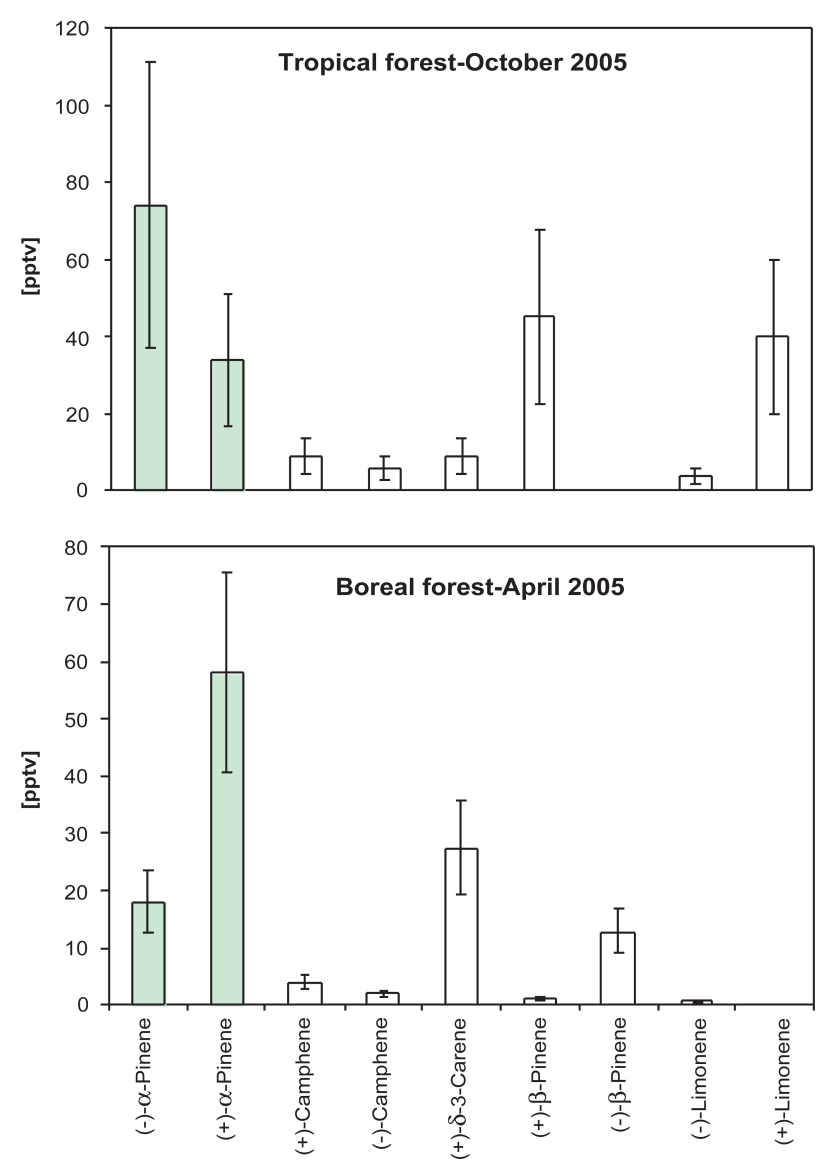

Fig. 5. Enantiomeric distributions of monoterpenes in Tropical forest (October 2005) and Boreal forest (April 2005). The enantiomers of $\alpha$-pinene are highlighted in green. Vertical bars show the range of the measurements.

greenhouses (ca. $300 \mathrm{~m}^{3}$ ) in the Mainz University Botanical garden, Germany. In all three cases an enantiomeric excess of ( - -) $\alpha$-pinene was found, consistent with our findings over the rainforest.

Most remarkable for the Tropical rainforest measurements was the correlation of the individual $\alpha$-pinene enantiomers with isoprene, shown in Fig. 6. While (+)- $\alpha$-pinene showed no significant correlation with isoprene, the $(-)-\alpha$-pinene enantiomer showed a significant correlation in the terrestrial boundary layer $(\mathrm{r}=0.6$, altitude range $0-2 \mathrm{~km})$. As the individual monoterpene enantiomers have not been considered in previous studies of this kind, one might reasonably assume the (+)- and (-)- $\alpha$-pinene correlate to some extent, or be emitted in response to the same stimuli, however, $(-)$ $\alpha$-pinene correlates much better with isoprene than it does with it's own mirror image enantiomer $(+)-\alpha$-pinene. This suggests that while $(-)-\alpha$-pinene emission is light dependent like isoprene, $(+)-\alpha$-pinene is temperature dependent only and therefore unlikely to be of significance in the Tropics. This hypothesis is consistent with our results from the 

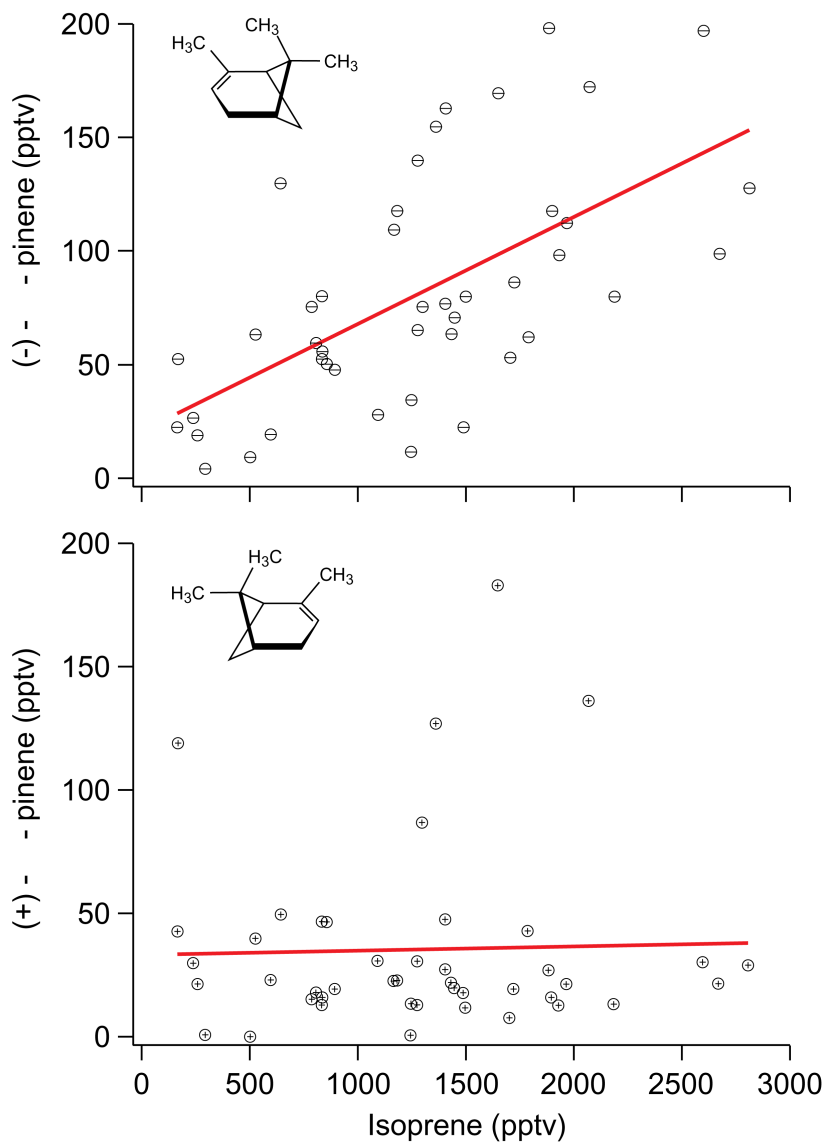

Fig. 6. Correlations of (-)- $\alpha$-pinene and (+)- $\alpha$-pinene with isoprene. The data presented were taken by aircraft over the forest between $0-2 \mathrm{~km}$. The enantiomeric structures of $(-)-\alpha$-pinene and $(+)-\alpha$-pinene are inserted top left in each panel.

Boreal forest which was (+)- $\alpha$-pinene dominated, see Fig. 5, since recent independent results from the same location have found that non-enantiomerically resolved $\alpha$-pinene emission rates could be described solely by a temperature dependent emission algorithm (Tarvainen et al., 2005). Furthermore the monoterpene emissions for Quercus ilex, which has been established to be predominately (-)- $\alpha$-pinene emitting (Yassaa et al., 2001), have been shown to fit a light and temperature dependent emission algorithm in independent studies (Plaza et al., 2005).

\section{Discussion}

We assume the broad scale predominance of (-)- $\alpha$-pinene in air over the biodiverse rainforest was biologically determined. However, previous enantiomeric analyses of individual tree xylem have shown highly variable enantiomeric ratios from $90 \%(-)-\alpha$-pinene to $80 \%(+)-\alpha$-pinene, even from different parts of the same tree (Norin, 1996; Fäldt et al., 2001). In contrast, the spatially and temporally more exten- sive ecosystem scale data presented here shows a clear enantiomeric predominance in ambient air, so what could be the underlying reason for the clear dominance of the (+)-form of $\alpha$-pinene over the Boreal forest and the $(-)$-form in air over the rainforest? The Boreal forest consists of a limited number of species types, predominately Scots pine (Pinus sylvestris) (Keronen et al., 2003). Thus the dominance of (+)- $\alpha$-pinene in Finland may simply reflect the emission pattern of the Scots pine. More difficult to elucidate is the enantiomeric preference exhibited by the very biodiverse rainforest. If the enantiomeric emission predominance of any given tree species is determined by chance one may expect a more or less even distribution of $(+)$ - and $(-)$ - $\alpha$-pinene emitters over a very heterogeneous ecosystem such as the rainforest. An alternative explanation to the light dependence of the $(-)-\alpha$-pinene presented in the preceding section would be that the strongest monoterpene emitters in this region of the rainforest are by chance predominately $(-)-\alpha$-pinene emitters (L. Cool, personal communication, 2006). It should, however, be remembered that the Tropical forest samples exhibiting the enantiomeric enhancement in (-)- $\alpha$-pinene were taken at different times of day (07:30-17:30 local time) and over several hundred kilometers. The effect seen in Fig. 6 is therefore not the result of a specific distribution of trees at a single location, as is the case in ground based rainforest studies, rather it is consistently observable over the entire Guyana region.

The natural world uses the air as a communication medium and such specific volatiles can signal opportunity to insects, pathogens and pollinators alike, or serve as a chemical defense (e.g. Croteau, 1987; Baldwin et al., 2006). The ecosystem relies on the atmosphere to rapidly oxidize these signaling compounds to preserve chemical gradients and thus the communication bandwidth. Trees, insects and even our own sense of smell can distinguish between certain enantiomeric monoterpenes since sensory organs are made up of proteins which are also chiral and hence chirally selective (Greer and Wainer, 2002). One possibility is that, in addition to the thermotolerance and antioxidant effects of $(-)-\alpha$-pinene emissions (Penuelas et al., 2005), it is advantageous for communication that certain monoterpenes are available throughout the ecosystem. Some insects (e.g. the bark beetle, Ips paraconfusus) can transform the specific monoterpene enantiomer $(-)-\alpha$-pinene where available, into a specific product (+)-cisverbenol which acts as an aggregation pheromone (Renwick et al., 1976). Such interactions are complex and usually investigated for single compounds and specific species of tree and insect. Since it has been established that the presence of one enantiomer can re-enforce, negate or enable the sensory effect of the other (Mori, 2002), the widespread presence of particular monoterpenes in the forest air may be considered as the "background noise" through which the vegetation communicates. 


\section{Conclusions}

We conclude that for future atmospheric chemistry, biological and ecological studies, the enantiomers of monoterpenes should be regarded and measured separately as distinct species. Moreover if insect/insect or insect/plant interactions are being investigated the distribution in air rather than solely in the xylem of individual species should be analysed, and this rainforest background distribution of monoterpenes considered in future experiments. The unexpected correlations between isoprene and the $\alpha$-pinene enantiomers shown here suggest that monoterpene responses to light and temperature may have been confused in the past because of the co-elution of the enantiomers. Perhaps the Tropical trees make use of the diel cycle in solar intensity in communicating with insects, whereas in Boreal latitudes the information would be obscured by the highly variable day length and the much stronger temperature variations. The implication is that many leaf scale studies of temperature and light responses (Owen et al., 2002), and large scale emission distribution measurements (Klinger et al., 2002; Geron et al., 2000) should be repeated with enantiomeric discrimination of monoterpenes, while there is a need to better understand forest emissions and genotype distribution. It should be noted, however, that the measurement of enantiomeric monoterpenes represents an increase in analytical difficulty. Since it has already been shown through non-enantiomeric VOC measurement intercomparisons that such determinations can be subject to large errors (Apel et al., 1994, 1999, 2003; Slemr et al., 2002), particular care must be taken with these measurements in the future. Accurate knowledge of monoterpenes will be essential for the accurate modelling of present and future atmospheric hydrocarbon emissions by forests, and recognise the sophistication of interactions between flora, fauna and the atmospheric environment.

Acknowledgements. We thank J. Kesselmeier, R. Winterhalter and J. Crowley from the Max Planck Institute for Chemistry in Mainz for helpful discussions. We also acknowledge the valuable comments provided through ACPD by L. Cool and G. Schade. We thank the workers of the Johannes Gutenberg-University Botanical garden for kindly providing access to the tropical greenhouses.

Edited by: A. Hofzumahaus

\section{References}

Apel, E. C., Calvert, J. G., and Fehsenfeld, F. C.: The nonmethane hydrocarbon intercomparison experiment (NOMHICE): Tasks 1 and 2, J. Geophys. Res., 99(D8), 16 651-16664, 1994.

Apel, E. C., Calvert, J. G., Gilpin, T. M., Fehsenfeld, F. C., Parrish, D. D., and Lonneman, W.A.: The Nonmethane Hydrocarbon Intercomparison Experiment (NOMHICE): Task 3, J. Geophys. Res., 104(D21), 26069-26 086, 1999.

Apel, E. C., Calvert, J. G., Gilpin, T. M., Fehsenfeld, F. C., and Lonneman, W. A.: Nonmethane Hydrocarbon Intercomparison
Experiment (NOMHICE): Task 4, ambient air, J. Geophys. Res., 108(D9), 4300, doi:10.1029/2002JD002936, 2003.

Atkinson, R. and Arey, J.: Gas Phase tropospheric chemistry of biogenic volatile organic compounds: a review, Atmos. Environ., 37, S197-S219, 2003.

Baldwin, I. T., Halitschke, R., Paschold, A., von Dahl, C. C., and Preston, C. A.: Volatile signaling in plant-plant interactions: "Talking trees" in the genomics era, Science, 311, 812-815, 2006.

Claeys, M., Graham, B., Gyorgy, V., Wang, W., Vermeylen, R., Pashynska, V., Cafmeyer, J., Guyon, P., Andreae, M. O., Artaxo, P., and Maenhaut, W.: Formation of secondary organic aerosols through photooxidation of isoprene, Science, 303, 1173-1176, 2004.

Croteau, R.: Biosynthesis and catabolism of monoterpenoids, Chem. Rev., 87, 929-954, 1987.

Fäldt, J., Sjodin, K., Persson, M., Valterova, I., and Borg-Karlson, A. K.: Correlations between selected monoterpene hydrocarbons in the xylem of six Pinus (pinaceae) species, Chemoecology, 11, 97-106, 2001.

Fuentes, J. D., Lerdau, M., Atkinson, R., Baldocchi, D., Bottenheim, J. W., Ciccioli, P., Lamb, B., Geron, C., Gu, L., Guenther, A., Sharkey, T. D., and Stockwell, W.: Biogenic hydrocarbons in the atmospheric boundary layer: A review, Bull. Am. Meteorol. Soc., 81, 1537-1575, 2000.

Geron, C., Rasmussen, R., Arnts, R. R., and Guenther, A.: A review and synthesis of monoterpene speciation from forests in the United States, Atmos. Environ., 34, 1761-1781, 2000.

Greer J. and Wainer, I. W.: Chapter 4, The molecular basis of chiral recognition, edited by: Lough, W. J. and Wainer, I. W., Chirality in Natural and Applied Science, CRC Press, Blackwell Publishing, Oxford, 2002.

Guenther, A., Hewitt, C. N., Erickson, D., Fall, R., Geron, C., Graedel, T., Harley, P., Klinger, L., Lerdau, M., Mckay, W.A., Pierce, T., Scholes, B., Steinbrecher, R., Tallamraju, R., Taylor, J., and Zimmerman, P.: A global-model of natural volatile organic compound emissions, J. Geophys. Res., 100, 8873-8892, 1995.

Houweling, S., Dentener, F., and Lelieveld, J.: The impact of nonmethane hydrocarbon compounds on tropospheric photochemistry, J. Geophys. Res., 103, $10673-10$ 696, 1998.

Keronen, P., Reissell, A., Rannik, U., Pohja, T., Siivola, E., Hiltunen, V., Hari, P., Kulmala, M., and Vesala, T.: Ozone flux measurements over a Scots pine forest using eddy covariance method: performance evaluation and comparison with fluxprofile method, Boreal Environ. Res., 8(4), 425-443, 2003.

Kesselmeier, J., Kuhn, U., Wolf, A., Andreae, M. O., Ciccioli, P., Brancaleoni, E., Frattoni, M., Guenther, A., Greenberg, J., Vasconcellos, P. D., de Oliva, T., Tavares, T., and Artaxo, P.: Atmospheric volatile organic compounds (VOC) at a remote tropical forest site in central Amazonia, Atmos. Environ., 34, 4063-4072, 2000.

Klinger, L. F., Li, Q. J., Guenther, A. B., Greenberg, J. P., Baker, B., and Bai, J. H.: Assessment of volatile organic compound emissions from ecosystems of China, J. Geophys. Res., 107(D21), 4603, doi:10.1029/2001JD001076, 2002.

Komenda, M., Kobel, K., Koppmann, R., and Wildt, J.: Comparability of biogenic VOC emission rate measurements under laboratory and ambient conditions at the example of monoterpene 
emissions from Scots Pine (Pinus Sylvestris), J. Atmos. Chem., 45(1), 1-23, 2003.

Komenda, M. and Koppmann, R.: Monoterpene emissions from Scots Pine (Pinus Sylvestris): Field studies of emission rate variabilities, J. Geophys. Res., 107(D13), 4161, doi:10.1029/2001JD000691, 2002.

Lerdau, M. and Gray, D.: Ecology and evolution of light-dependent and light-independent phytogenic volatile organic carbon, New Phytologist, 157, 199-211, 2003.

Mori, K.: Chapter 9 Chirality in the natural world: Chemical communications, edited by: Lough, W. J. and Wainer, I. W., Chirality in Natural and Applied Science, CRC Press, Blackwell Publishing, Oxford, 2002.

Muller, J. F.: Geographical distribution and seasonal variation of surface emissions and deposition velocities of atmospheric trace gases, J. Geophys. Res., 97, 3787-3804 1992.

Norin, T.: Chiral chemodiversity and its role for biological activity. Some observations from studies on insect/insect and insect/plant relationships, Pure Appl. Chem., 68, 2043-2049, 1996.

Nunes, F. M. N., Veloso, M. C. C., Pereira, P. A. D. P., and de Andrade, J. B.: Gas-phase ozonolysis of the monoterpenoids (S)(+)-carvone, (R)-(-)-carvone, (-)-carveol, geraniol and citral, Atmos. Environ., 39, 7715-7730, 2005.

Owen, S. M., Harley, P., Guenther, A., and Hewitt, C. N.: Light dependency of VOC emissions from selected Mediterranean plant species, Atmos. Environ., 36, 3147-3159, 2002.

Penuelas, J., Llusia, J., Asensio, D., and Munne-Bosch, S.: Linking isoprene with plant thermotolerance, antioxidants and monoterpene emissions, Plant Cell Environ., 28, 278-286, 2005.

Persson, M. Borgkarlson, A. K., and Norin, T.: Enantiomeric composition of 6 chiral monoterpene hydrocarbons in different tissues of Pica-Abies, Phytochem., 33(2), 303-307, 1993.

Plaza, J., Nunez, L., Pujadas, M., Perrez-Pastor, R., Bermejo, V., Garcia-Alonso, S., and Elvira, S.: Field monoterpene emission of Mediterranean oak (Quercus ilex) in the central Iberian Peninsula measured by enclosure and micrometeorological techniques: Observation of drought stress effect, J. Geophys. Res., 110(D3), D01105, doi:10.1029/2004JD005168, 2005.

Renwick, J. A. A., Hughes, P. R., and Krull, I. S.: Selective production of cis and trans-verbenol from (-) and (+) alpha pinene by a bark beetle, Science, 191, 199-201, 1976.

Rinne, H. J. I., Guenther, A. B., Greenberg, J. P., and Harley, P. C.: Isoprene and monoterpene fluxes measured above Amazonian rainforest and their dependence on light and temperature, Atmos. Environ., 36(14), 2421-2426, 2002.

Seinfeld, J. H. and Pankow, J. F.: Organic atmospheric particulate material, Ann. Rev. Phys. Chem., 54, 121-140, 2003.
Shao, M., Czapiewski, K. V., Heiden, A. C., Kobel, K., Komenda, M., Koppmann, R., and Wildt, J.: Volatile organic compound emissions from Scots pine: Mechanisms and description by algorithms, J. Geophys. Res., 106, 20 483-20 492, 2001.

Sjödin, K., Persson, M., Fäldt, J., Ekberg, I., Borg-Karlson, A. K.: Occurrence and correlations of monoterpene hydrocarbon enantiomers in Pinus sylvestris and Picea abies, J. Chem. Ecology, 26(7), 1701-1720, 2000

Sjödin, K., Persson, M., BorgKarlson, A. K., and Norin, T.: Enantiomeric compositions of monoterpene hydrocarbons in different tissues of four individuals of Pinus sylvestris, Phytochem., 41(2), 439-445, 1996.

Slemr, J., Slemr, F., Partridge, R., D'Souza, H., and Schmidbauer, N.: Accurate Measurements of Hydrocarbons in the Atmosphere (AMOHA): Three European intercomparisons, J. Geophys. Res., 107(D19), 4409, doi:10.1029/2001JD001357, 2002.

Spirig, C., Guenther, A., Greenberg, J. P., Calanca, P., and Tarvainen, V.: Tethered balloon measurements of biogenic volatile organic compounds at a Boreal forest site, Atmos. Chem. Phys., 4, 215-229, 2004, http://www.atmos-chem-phys.net/4/215/2004/.

Tarvainen, V., Hakola, H., Hellén, H., Bäck, J., Hari, P., and Kulmala, M.: Temperature and light dependence of the VOC emissions of Scots pine, Atmos. Chem. Phys., 5, 989-998, 2005, http://www.atmos-chem-phys.net/5/989/2005/.

Wang, Y. H., Jacob, D. J., and Logan, J. A.: Global simulation of tropospheric O-3-NOx-hydrocarbon chemistry 3. Origin of tropospheric ozone and effects of nonmethane hydrocarbons, J. Geophys. Res., 103, 10 757-10 767, 1998.

Williams, J.: Organic trace gases: An overview, Environ. Chem., 1, 125-136, 2004.

Yassaa, N., Brancaleoni, E., Frattoni, M., and Ciccioli, P.: Trace level determination of enantiomeric monoterpenes in terrestrial plant emission and in the atmosphere using a $\beta$-cyclodextrin capillary column coupled with thermal desorption and mass spectrometry, J. Chromatogr. A, 915, 185-197, 2001.

Yassaa, N. and Williams, J.: Analysis of enantiomeric and nonenantiomeric monoterpenes in plant emissions using portable dynamic air sampling/solid-phase microextraction (PDASSPME) and chiral gas chromatography/mass spectrometry, Atmos.Environ., 39, 4875-4884, 2005.

Yassaa, N. and Williams, J.: Enantiomeric monoterpene emissions from natural and damaged Scots pine in a boreal coniferous forest measured using solid-phase microextraction and gas chromatography/mass spectrometry, J. Chromatogr. A., 1141(1), 138-144, doi:10.1016/J.Chroma.2006.12.006, 2007. 